Ewa Kobyłecka

University of Zielona Góra

\title{
On teachers' potential in promoting pupils' emotional and spiritual development at school
}

\section{ABSTRACT}

Contemporary adolescents are tempted by effortless, consumerist lifestyles devoid of reflection. They display pretentious attitudes and exhibit problems with proper functioning within the society. Therefore, it is necessary to change educational processes at school in order to promote intensive emotional and spiritual development in pupils, so that young generations comprehensively develop to handle future problems, as well as to be able to construct their own knowledge about themselves and the outside world. Competent teachers can play certain roles in this process, introducing their pupils into the rich world of values.

Key words: development, emotional intelligence, spirituality, axiological competences, values

\section{INTRODUCTION}

Contemporary times are characterised by rapid social and cultural changes. Negative phenomena threatening proper functioning of individuals and communities, such as pathologies, nationalism or terrorism are multiplying. For this reason, many of us feel existential angst, fear of the future, axiological confusion. In particular, the representatives of the younger generation are prone to frustra- 
tion. Critical, rebellious, they ask questions about the meaning of human existence in the world, searching for their own path to follow. The opinions of peers or admired idols and celebrities are often more important than the opinions of parents, guardians and educators. Pupils imitate the behaviour of others, and do not always reflect on the consequences of their own actions and artefacts. Popular culture gains popularity, which generally fails to build a consistent normative order. For many people, what is happening now is of prime importance and easy, prosperous, pleasant life, preferably in the limelight, has become a principal, aspirational target for a large group of adolescents.

The cost of technological revolution manifests itself in a crisis of the ideas of humanism, in deficiently developed empathy, in upset emotional stability, in a sense of loneliness and exclusion of a large number of individuals. Increasingly, physical attractiveness and fitness, popularity or financial independence constitute a key quality measure. In some social environments, modesty, generosity, selflessness, honesty or truthfulness are interpreted as a manifestation of naivety, weakness, lack of resourcefulness and cunning, whereas concern about providing young people with decent life goals, desired for their individual development and useful from the perspective of the community, should be of utmost importance.

Intensification of school initiatives meant to promote pupils' emotional and spiritual development is essential for pupils to comprehensively develop in order to meet challenges posed before them, so that they are primarily able to construct their own knowledge about themselves, others and the world. A significant role in this process can be played by competent teachers.

\section{IMPROVEMENT OF THE EMOTIONAL SPHERE}

Emotions and spiritual life determine conscious and unconscious existence of individuals. The subconscious mind contains the unused knowledge of human psychological origins. In general, we make little use of intuition in our vision of reality. We excessively worry, we are depressed, nervous, sad, rather than creatively and optimistically solve problems (Peirce, 2001, pp. 99-100). Feelings, desires and passions play a central role in human psyche. It is them rather than reason that we predominantly use in difficult, exceptional situations, where we need to quickly make some important decisions. 
There is no simple answer to the question of what emotions are. The following may be indicated:

1. Emotion is usually instigated by conscious or unconscious evaluation of an event as a significant concern.

2. The core of emotions is readiness to act and prompt plans; a specific emotion gives priority to one or more types of action, imposing a sense of their urgency. Therefore, it may interfere with alternative mental processes or activities or compete with them.

3. A specific emotion is usually experienced as a separate type of a mental state, which is sometimes accompanied or followed by somatic changes, as well as acts of expression and initiative (Oatley \& Jenkins, 2003, p. 95).

Educational activities, fulfilling informative, controlling and motivational functions, require emotional involvement on the part of teachers and pupils, the source of which lies in emotional intelligence. It is thanks to it that pupils' adequate self-assessment, critical attitude to their own advantages and disadvantages, ability to owe to mistakes, humility, mature reflection on others and the surrounding reality are all possible. We can both talk of comprehensive (self-esteem) and detailed self-assessment, the former being a relatively stable disposition of individuals and the latter concerning their functioning in various areas of their existence (see: Dzwonkowska, Lachowicz-Tabaczek, Łaguna, 2008). Self-esteem fluctuates during the course of human life, depending on particular personality traits. Social psychologists distinguish four main paths to self-knowledge: a) introspection (reflection on ourselves and what we think and feel); b) observation of own behaviour (evaluation, comparison with internal standards and values); c) 'I' schemes, i.e. structures of self-knowledge, our own thoughts, beliefs or personality traits, which help to understand, explain and predict our own behaviour; d) social interaction, which involves acquisition of self-knowledge through comparison with others and defining how we are perceived by the other party (Aronson, Wilson, Akert, 1997, pp. 205-257).

These paths, whose actualisation requires improvement in individuals' emotional sphere, influence the effectiveness of all conscious and habitual measures, a fact which is not sufficiently appreciated in education. In a typical school, we can see a great emotional distance between teachers and pupils. Educators generally know little about the children that they are in charge of, they fail to notice their problems, they tend to dominate, make demands and 
instruct. In large educational institutions, young people can feel lonely and anonymous. They are unwilling or unable to talk about their everyday worries and joys, but learn to be good at hiding their weaknesses. Therefore, more attention in the pedagogical process should be devoted to the development of such qualities as: empathy, independence, persistence, self-control, kindness, good manners, care, and altruism, showing respect to others and friendly attitude towards people and the world (Shapiro, 1997).

Emotional intelligence includes: "the ability to be motivated and to persevere in pursuing goals despite setbacks, the ability to control impulses and postpone their satisfaction, to regulate mood and not to surrender to worries which disable cognitive capacity, to empathise with other people's moods, as well as to optimistically look into the future" (Goleman, 1997, p. 67). It is also home to emotional competence, which facilitates achievement of successful outcomes. Emotional intelligence determines potential ability to learn practical skills in coping in life situations, such as: self-awareness, motivation, independence, empathy and good relations with others. It shows how many of these potential abilities can be successfully converted into useful everyday skills (Goleman, 1999, p. 46). Below is presented a link between five dimensions of emotional intelligence and twenty-four instances of emotional competence that are worth improving by those in charge of human resources (Goleman, 1999, pp. 48-50):

I. Personal competence (determines the extent to which we deal with each other).

1. Self-awareness (knowledge about own internal states, preferences, capabilities and intuitive valuations): a) emotional awareness (recognising own emotions and their effects); b) correct self-esteem (knowledge of strengths and limitations); c) self-confidence (strong self-esteem and awareness of own abilities and skills).

2. Self-regulation (control over internal states, impulses and possibilities): a) self-control (control over internal emotions and impulses); b) trustworthiness (maintaining honesty and integrity standards);c) conscientiousness (assuming responsibility for own actions); d) adaptability (flexibility in adaptation to changes); e) innovation (easy adoption of innovative ideas, attitudes and new information).

3. Motivation (emotional tendencies that lead to new targets or facilitate their achievement: a) pursuing achievements (efforts for get 
better results or meet criteria of excellence); b) commitment (identification of own goals with collective objectives of a group, organisation or institution); c) initiative (readiness to seize chances and opportunities); d) optimism (perseverance in trying to achieve the pursued objectives despite obstacles and setbacks).

II. Social Competence (the competence determines the extent to which we deal with others):

4. Empathy (identification of feelings, needs and anxieties of other people): a) understanding others (sensing the feelings and perspectives of others and active interest in their concerns, anxieties, worries); b) improving others (awareness of other developmental needs and improvement of their potential); c) service-oriented attitude (anticipation, identification and satisfaction of the needs of others); d) encouraging diversity (creation and maintenance of achievement opportunities through the use of different types of people).

5. Social skills (ability to induce desired responses in others): a) influencing others (mastering methods of effective persuasion); b) communication (listening without prejudice and sending convincing messages); c) mitigation of conflicts (mediation in disputes and their resolution); d) leadership (inspiring individuals and groups or directing them); e) catalysing changes (initiating or managing changes); f) establishment of ties (nurturing instrumental relationships with others); g) cooperation (working with others toward a common goal); h) collective abilities (organising cooperation of all members of a group to achieve a collective goal).

This list makes it possible to put together teachers' (class leaders') and their pupils' (people who enter in an increasingly complex relationships with others) strengths and to find skills that can be improved in the course of learning. Research shows that, compared with the IQ and expertise, emotional competence is twice as important in effective initiatives, regardless of a held position and a working place (Goleman, 1999, p. 55). Teachers must well know themselves and their pupils to be able to support them in their development. Such flaws as blind ambition, unrealistic objectives and excessive demands, workaholism, selfishness, unsatisfied need of recognition, attention to appearances, the need to appear perfect, may all interfere with carers' successful initiatives at school (Goleman, 1999, p. 100). 
All individuals (particularly those who work with groups of people) are in need of developed interpersonal intelligence that expresses itself in their ability to understand other people, their motivation, moods, feelings, as well as to predict their behaviour and interpret their desires. In contrast, refined intrapersonal intelligence makes it possible to create accurate and realistic self-image and use this image to perform effective actions (Gardner, 2002, pp. 46-49). Interactions between teachers and pupils should be rooted in respect, dignity and acceptance of all participants in the educational process. Modern school is in need of educators who do not impose their own or textbook interpretations onto the presented educational content and make room for pupils' individual decisions. Classes should feature as many discussions as it is possible, e.g. on individual tastes, preferences, human emotions, ethics or worldview preferences. Concern about the development of young people is manifested in caregivers taking measures to support the formation of their pupils' personal culture and care for their high moral standards.

It is also important for young people to be able to solve different interpersonal problems, to learn to conduct conversations or negotiations. The goals of effective communication include developing skills: a) to communicate in a simple, clear, non-judgemental manner, avoiding attribution; b) to inquire to analyse own behaviour and conduct experiments on their own operation in the world; c) to resolve conflicts and disputes without coercion and manipulation (Aronson, 2000, p. 382).

All these dispositions facilitate entering and maintaining friendships and functioning in peer groups, which in turn secures pupils' basic needs, immunises them against failures, adapts to changes and aids in controlling negative emotions.

At school, individuals widen their circle of their friends, thus, undergo socialisation. They learn to cooperate in a variety of formal and informal teams and to share responsibility for initiatives cooperatively undertaken with teachers. A very valuable initiative to promote pupils' emotional development is to involve them in work towards school community (e.g. by helping with homework and organising young pupils' free time at breaktime), as well as participation in volunteering initiatives (care of animals in winter, preparing Christmas gifts for children from orphanages or collecting money for those in need of material support, etc.). Ready-made action plans, streamlining the process of the development of interpersonal intelligence (Silberman, Hansburg, 2012, pp. 264-267), may be created or used in school (classroom). Also, teachers 
may be motivated to familiarise themselves with programs of Upgrading Social Skills; Creative Conflict Resolution and other (Goleman, 1997, pp. 466-468). They should be encouraged to talk to pupils on everyday basis (not just during class meetings) about their achievements in self-development, to cross their own limitations and weaknesses, to incite them to share their attempts at emotional self-control and to mobilise them to correct their behaviour, especially if it may be offensive. Moreover, teachers should introduce exercises shaping assertiveness, positive from the perspective of social attitudes and values.

Educational institutions should direct more attention to the development of dispute-settling and conflict-resolving skills, in order to build good relationships with others and cooperate for the benefit of the community. Also here, the transfer of knowledge about emotions is necessary, which can be considered as a factor stimulating initiatives and influencing moral behaviour: 1) anticipation of emotional rewards and punishments, taking them into account in the decision-making process; 2) direct stimuli triggering empathic behaviour (mercy, compassion); 3) compensatory initiatives in relation to addressees of previously negative behaviour (Pawlik, 2009, p. 250).

Thanks to greater focus on supporting pupils' emotional development, schools become places where pupils feel respected, connected with classmates, schoolmates, teachers and the educational institution itself. They know that others engage in their well-being, that they care about them (Goleman, 1997, p. 431).

\title{
INTRODUCTION OF SPIRITUALITY INTO THE PROCESS OF EDUCATION
}

\begin{abstract}
A considerable proportion of scientists agree with the opinion that in the 20th century saw a regression of morality and humanity. Rapid technological development and consumerist attitudes to life brought about uniformity of culture. Daily functioning at the beginning of the 21 st century is marked by a stigma of an identity crisis in contemporary people, who are lost in the chaos of conflicting information and are not able to build their own system of values and ideals. The mass media promote both positive and negative pat-
\end{abstract}


terns. Their magnanimous, heroic images of human behaviour hardly counterbalance whatever reigns in tabloids, i.e.: sensationalism and tragic, cruel, violent or evil events/deeds.

Therefore, supporting the development of pupils' self-awareness and spirituality is another very important task to be addressed by schools and teachers. Spirituality is such an attitude towards the surrounding reality which "inclines to seeking a connection with the transcendence of the meaning of the existence of the world and the meaning of human existence" (Bokszański, 2010, p. 36). Its essence is seen in the conviction that "there is a reality beyond the material, superior to 'I', only fragmentarily available to human cognition, yet exerting influence on the sphere of feelings and behaviour" (Jackowska, 2010, p. 51). In psychology, spirituality is treated as a structural element of personality, associated with emotions, rational thought, affection or self-knowledge. It has three components: 1) cognitive (looking for the key to understanding the theory of existence of the world and own existence and identity beyond the material realm); 2) emotional (expressed in emotions and feelings towards the Absolute, unknowable to reason beyond-material reality); 3) motivational (conducive to such forms of activity as prayer, meditation, charity, asceticism, etc.) (Jackowska, 2010, p. 52).

The development of spirituality has an impact on making mature decisions, on wellbeing and psychophysical condition, and as such, it is dependent on the conditions in which young people develop (style, upbringing methods favoured by carers, provided role models, internal and external motivation). Spirituality connects with identity (typically understood as an independent way of the functioning of consciousness), associated with autonomy, activity, responsibility, dignity and self-knowledge (Adamiec, 1994). Being treated as an entity (or having a potential of becoming one) is considered as a non-instrumental positive value that is worth achieving, nurturing and protecting. Pupils who have a sense of being entities co-create the educational reality, are more resourceful than their peers, are aware of their own identity and are less prone to excessive stress, fears and frustrations.

Thanks to spirituality, people open up to universal values and transcendent to infinity. As intelligent entities, they have the right to self-determination, have free will and should be independent in their activities. Young people are usually sensitive to truth, justice, beauty, want to find themselves (John Paul II, 2008, p. 524). Humans live in the material and spiritual world. Especially today, it is necessary to develop not only the mind, but also the conscience, 
moral sensitivity, because people often lack a deeper reflection on the essence of their own existence.

Sensitive, wise teachers-educators assist their pupils' activities that help to perceive the richness of values in the world (in intellectual, emotional and spiritual dimensions). They support the improvement of pupils' axiological competence, consisting of both knowledge about values, and skills to recognise (identify), understand (define), evaluate, select, differentiate, approve and respect (implement) values, accompanied by their willingness to multiply them and create new ones (Kobyłecka, 2009).

Therefore, in my opinion, future teachers must be prepared or inspired to self-preparation in the course of their training, in order to assume professional roles of guides (triggering authority: constructively influencing pupils' attitudes and behaviour, mobilising them to make their own decisions, deepening their sense of responsibility and affecting the levels of their self-esteem), advisers, interpreters of reality (inspiring narratives and negotiations, showing the multiplicity of cultures, proposing navigation through meanings), and managers who introduce young people to participate in culture (motivating, incorporating and developing interests, promoting art in an attractive and accessible manner). In the current difficult times of civilisational transformation, creative teachers are in demand. In other words, teachers who flexibly implement the curricular content, are democratic and know how to see situations from their pupils' point of view.

Education to creativity and through creativity seems to be one of the most important tasks of school. Therefore, there should always be time for innovative approaches, individualism, discussions about inner life or conversations about art in the classroom. Also, pupils' emotional and spiritual development can be significantly boosted by their exposure to literature, through which young people learn to understand feelings, as well as eternal themes of human behaviour through experiencing them while reading valuable epic, lyrical and dramatic literary creations.

Humans are entities immersed in culture, which shapes them and they express though it. Thanks to it, they are more humane, sharing what they have with others in the family, school, community and society. Knowledge of culture is needed for broad discussions with others, to understand each other and build a civilisation of peace.

Each organism as a whole has "a certain wisdom and purposefulness that go far beyond conscious thought” (Rogers, 2002, p. 121). Emotions and states 
of consciousness play a special role in the acceptance and respect of what is important and valuable, facilitate decision making, the choice between good and evil, what to support and protect, and what to reject or deem undesirable (Łosiak, 2007, p. 217). Individuals who do not develop spiritually are not capable of selfless love, altruism, generosity and acceptance of responsibility for the community in which they function. Only constant enrichment of the inner world, opening up to a variety of experiences, great ideas and eternal values, and also openness towards another person can make life meaningful and happy.

\section{CONCLUSIONS AND POSTULATES}

Undoubtedly, there are miscellaneous possibilities for pupils' emotional and spiritual development, conditioned culturally, philosophically, ideologically, socially and pedagogically. Promotion of measures that are meant to strengthen the bonds between people, to nurture good relationships, to instigate positive attitudes, to improve the skills of self-control, to encourage to contemplation and meditation, is of utmost importance. Comprehensive development of humans that will motivate them to reach for lofty goals and to support their efforts to achieve them, is one of the most important objectives of education. Modern school cannot live merely through intellectual activity. Creative attitudes of teachers and pupils should be promoted and educational participants should be encouraged to undertake all measures of self-creation and support towards the formation of mature personalities.

Here are some, in my opinion, important postulates for school practice:

1. It is necessary to significantly expand teachers' knowledge about emotions and spirituality through external influences (change in academic curricula, development of textbooks, organising courses improving emotional competence of school teachers, etc.), and internal (systematic work in the field of acquisition and application of psychological, ethical, axiological knowledge).

2. It is of utmost importance that educators become familiar with their pupils, their problems, worries and joys, as well as with themselves, their own psyche, inner life, the world of values, i.e. immediate and distant objectives and meanings of professional and personal existence. 
3. The school cannot merely function through intellectual activity. Emotions, imagination and creative attitudes must be actively promoted. All these types of activities should be communicated to future educators in the course of teacher-training. Animation of high culture is also indispensable in educational institutions.

4. Students, future teachers, should be provided with careful and comprehensive preparation for various forms of social activity aimed at selfless help to others, voluntarism.

5. Schools should organise trainings for educators, e.g. in the field of development of interpersonal intelligence (Silberman \& Hansburg, 2012), multiple intelligences (Gardner, Kornhaber, Wake, 2001); formation of emotional competence (Goleman, 1999).

6. Teachers and pupils should be able to co-decide to a greater extent on the content and methods of education, become creators of themselves and their own educational activities.

7. Emotional and spiritual life should be communicated during lessons, controlling emotions, such as anger, should be taught on everyday basis; there should be talk about pain felt because of rejection, jealousy, fear, remorse, misunderstandings, conflicts or fights.

Education of humans is "more about 'being', and not only about 'having' so that by means of what they 'have', 'possess', they are more able to be fully human - that is, that they also know how to 'be', not only with 'others', but also for 'others'” (John Paul II, 1988, p. 58). The prime objective of education is to support pupils, entities that would become more mature, more perfect and fully realising all their potential and talents. More attention should be paid to the teaching of critical and creative thinking, free from patterns and stereotypes, to creation of educational programs with emphasis on pupils' self-understanding, as well as understanding others and the world.

\section{REFERENCES:}

ADAMIEC, M. (1992), Podmiotowość - formy i zmiany, in: Podmiotowość człowieka. Szanse rozwoju i zagrożenia, Z. Ratajczak (ed.), Wydawnictwo Uniwersytetu Śląskiego, Katowice. 
ARONSON, E. (2000), Człowiek istota społeczna, translated by: J. Radzicki, PWN, Warszawa.

ARONSON E., Wilson, T.D., Akert, R.M. (1997), Psychologia społeczna. Serce i umyst, translated by: A. Bezwińska, „Zysk i S-ka”, Poznań.

BOKSZAŃSKI Z. (2010), Podmiotowość a wspótczesna teoria socjologiczna, in: Duchowy wymiar istnienia, K. Obuchowski, M.K. Stasiak (eds.), Wydawnictwo Akademii Humanistyczno-Ekonomicznej w Łodzi, Łódź.

DZWONKOWSKA, I., Lachowicz-Tabaczek, K., Łaguna, M. (2008), Samoocena i jej pomiar. Polska adaptacja skali SES M. Rosenberga, Pracownia Testów Psychologicznych, Warszawa.

GARDNER, H. (2002), Inteligencje wielorakie. Teoria w praktyce, translated by: A. Jankowski, „Media Rodzina”, Poznań.

GARDNER, H., Kornhaber, M.L. Wake, W. K (2001), Inteligencja. Wielorakie perspektywy, translated by: M. Groborz, M. Śmieja, WSiP, Warszawa.

GOLEMAN, D. (1997), Inteligencja emocjonalna, translated by: A. Jankowski, Media Rodzina, Poznań.

GOLEMAN, D. (1999), Inteligencja emocjonalna w praktyce, translated by: A. Jankowski, Media Rodzina, Poznań.

JACKOWSKA, E. (2010), Wymiar duchowości w strukturze zintegrowanej osobowości, in: K. Obuchowski, M.K. Stasiak, Duchowy wymiar istnienia, K. Obuchowski, M.K. Stasiak (eds.), Wydawnictwo Akademii Humanistyczno-Ekonomicznej w Łodzi, Łódź.

JAN Paweł II (2008), Przemówienie do katechetów, nauczycieli i uczniów, in: Dzieła zebrane. Homilie i przemówienia z Pielgrzymek - Europa. Cz. 1. Polska, Kraków.

JAN Paweł II (1988), Wiara i kultura, RW KUL, Rzym-Lublin.

KOBYŁECKA, E. (2014), Edukacja aksjologiczna w przestrzeni szkolnej codzienności, in: Codzienność szkoły. Uczeń, E. Bochno, I. Nowosad, M.J. Szymański (eds.), Oficyna Wydawnicza „Impuls”, Kraków.

KOBYŁECKA, E. (2009), Nauczyciele i uczniowie gimnazjum wobec wyboru wartości. Między pewnością a zwattpieniem, Oficyna Wydawnicza UZ, Zielona Góra.

PSYCHOLOGIA emocji (2005), M. Lewis, J.M. Haviland-Jones (eds.), translated by: M. Kacmajor, P. Kołyszko, GWP, Gdańsk.

ŁOSIAK, W. (2007), Psychologia emocji, Wydawnictwa Akademickie i Profesjonalne, Warszawa.

OATLEY, K., Jenkins, J.M. (2003), Zrozumieć emocje, translated by: J. Radzicki, J. Suchecki, Wydawnictwo Naukowe PWN, Warszawa.

PAWLIK, W. (2009), Lęk, wstyd wina. W stronę socjologii emocji, in: Emocje a kultura i życie społeczne, (eds.) P. Bindera, H. Palska, W. Pawlik, Wydawnictwo IFiS PAN, Warszawa. 
PEIRCE, P. (2001), Intuicja. Jak stuchać wskazówek wewnętrznego głosu, translated by: J. Listwan, Wydawnictwo MEDIUM, Konstancin-Jeziorna.

ROGERS, C.R. (2002), Sposób bycia, translated by: M. Karpiński, „Rebis”, Poznań. SHAPIRO, L.E. (1997), Jak wychować dziecko o wysokim EQ translated by: T. Geller, Prószyński i S-ka, Warszawa.

SILBERMAN, M., Hansburg F. (2012), Inteligencja interpersonalna. Jak utrzymać madre relacje $z$ innymi, translated by: D. Piotrowska, Studio EMKA, Warszawa.

WOJNAR, I. (2000), Humanistyczne intencje edukacji, Wydawnictwo Akademickie „Żak”, Warszawa. 